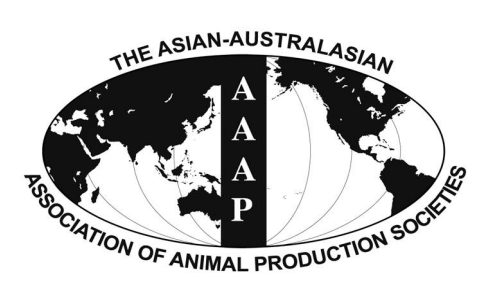

\title{
Effects of Forage:Concentrate Ratio on Growth Performance, Ruminal Fermentation and Blood Metabolites in Housing-feeding Yaks
}

\author{
G. J. Chen, S. D. Song, B. X. Wang, Z. F. Zhang, Z. L. Peng, C. H. Guo*, J. C. Zhong, and Y. Wang \\ Southwest University for Nationalities, College of Life Science and Technology, Chengdu, 610041, China
}

\begin{abstract}
The objective of this study was to determine the effect of forage: concentrate ratio (F:C) on growth performance, ruminal fermentation and blood metabolites of housing-feeding yaks. Thirty-two Maiwa male yaks (initial body weight $=207.99 \pm 3.31$ $\mathrm{kg}$ ) were randomly assigned to four dietary treatments (8 yaks per treatment). Experimental diets were: A, B, C, D which contained 70:30, 60:40, 50:50 and 40:60 F:C ratios, respectively. Dry matter intake and average daily gain in yaks fed the C and D diets were greater $(\mathrm{p}<0.05)$ than yaks fed the A and $\mathrm{B}$ diets. No differences were found in ruminal $\mathrm{NH}_{3}-\mathrm{N}$, total volatile fatty acids, acetate, butyrate, valerate, and isovalerate concentrations. The propionate concentration was increased $(p<0.05)$ in the $C$ and $D$ groups compared with the $A$ and $B$ diets. In contrast, the acetate to propionate ratio was decreased and was lowest $(p<0.05)$ in the $C$ group relative to the $A$ and B diets, but was similar with the D group. For blood metabolites, no differences were found in serum concentrations of urea-N, albumin, triglyceride, cholesterol, low density lipoprotein, alanine aminotransferase, and aspartate aminotransferase ( $p>0.05)$ among treatments. Treatment $\mathrm{C}$ had a higher concentration of total protein and high density lipoprotein $(\mathrm{p}<0.05)$ than $\mathrm{A}$ and $\mathrm{B}$ groups. In addition, there was a trend that the globulin concentration of A group was lower than other treatments $(p=0.079)$. Results from this study suggest that increasing the level of concentrate from $30 \%$ to $50 \%$ exerted a positive effect on growth performance, rumen fermentation and blood metabolites in yaks. (Key Words: Blood Metabolites, Forage:Concentrate Ratio, Growth Performance, Ruminal Fermentation, Yak)
\end{abstract}

\section{INTRODUCTION}

Yaks (Bos grunniens) are found extensively on the plateau of western of China in Himalayas and subalpine regions at altitudes of 2,000 to $5,000 \mathrm{~m}$ with a cold, semihumid climate. The yak is largely dependent on natural pastures for its survival. Thus, the nutritional state of yaks varies seasonally as the supply of supplementary feeds is limited (Long et al., 2008). Low calving and growth rates are attributed to the poor nutritional condition of yaks, especially in the cold season. The traditional way of feeding the animals is to allow them to put on as much fat as possible during the warm season, which can be used during the cold season. However, there is a tendency toward which the above-mentioned situation cannot meet the marketable

\footnotetext{
* Corresponding Author: C. H. Guo. Tel: +86-18113045598, Fax:+86-028-85528869, E-mail: www.gch33@aliyun.com Submitted May 11, 2015; Revised Jun. 1, 2015; Accepted Jul. 4, 2015
}

need of yak production and hence, increased research on the optimal nutritional and feeding strategies of yaks is being conducted (Long et al., 1999; Long et al., 2005; Dong et al., 2006).

The incorporation of concentrates in ruminant diets is intended to increase the energy, proteins, minerals, and vitamins intake of the animal. The feed utilization, productive efficiency, and the fiber digestion may depend on the nature of the concentrate (Morand-Fehr and Sauvant, 1987). However, long-term feeding a high-concentrate diet causes a decreased ruminal $\mathrm{pH}$ value due to the accumulation of volatile fatty acids (VFA) and lactic acid, and a chronic digestive disorder known as subacute ruminal acidosis may occur (Chen et al., 2012). Therefore, determining the appropriate concentrate level is one of the most important factors to ensure the growth and health of house-fed yaks.

The objective of this study was to evaluate the effects of $\mathrm{F}: \mathrm{C}$ on growth performance, ruminal fermentation and 
blood metabolites of house-fed yaks.

\section{MATERIAL AND METHODS}

\section{Study site}

The study was conducted at Xiaojin County in Aba Tibetan and Qiang Autonomous Prefecture, western Sichuan Province of China $\left(\mathrm{N} 30^{\circ} 35^{\prime}, \mathrm{E} 102^{\circ} 01^{\prime}\right)$. This area is over $2,500 \mathrm{~m}$ above sea level and has a dry cold climate. The annual average temperature is $12.2^{\circ} \mathrm{C}$ and the average yearly precipitation is $613.9 \mathrm{~mm}$ of rain. The study lasted from December 2014 to February 2015, which is the coldest season of the year (the temperature varies from -3 to $12^{\circ} \mathrm{C}$ in the colony house of yaks).

\section{Experimental design, diets and management}

A total of 32 3-year-old uncastrated Maiwa male yaks $(207.99 \pm 3.31 \mathrm{~kg}$ of body weight [BW]) were randomly divided into 4 groups with 8 replicates of 1 yak. Yaks were allocated into individual pens $\left(4 \mathrm{~m}^{2}\right.$ for each yak) within a barn. The main effect was the level of concentrate in the diet. Treatments contained four forage to concentrate ratios (on dry matter [DM] basis): A (70:30), B (60:40), C (50:50), $\mathrm{D}$ (40:60). The chemical composition of forage (corn straw) was as follows: $80.15 \% \mathrm{DM}, 5.04 \%$ crude protein, $1.30 \%$ ether extract, $7.07 \%$ ash, $44.23 \%$ acid detergent fiber (ADF), and $70.27 \%$ neutral detergent fiber (NDF) (DM basis). The ingredients and nutrient composition of the diets in each group are given in Table 1. Animals had free access to water throughout the experiment. Concentrate and forage were manually mixed (according to experiment design) and bagged off site, and sufficient diets were prepared for the entire study. The yaks were fed the mixed diets twice daily, at $08: 00$ and $16: 00 \mathrm{~h}$ for ad libitum intake (5\% to $10 \%$ refusals). The experiment lasted for $60 \mathrm{~d}$ (2014-12-8 to 2015-2-5), and the amounts of feed offered and refused were recorded daily for each animal throughout the trial. Body weight was measured at the beginning and the end of the experiment.

\section{Measurements, sample collection and analyses}

The feed intake was determined daily for each animal. Average daily gain (ADG) was calculated for throughout the trial. Feed efficiency was calculated as the ratio between ADG and dry matter intake (DMI).

A total of $100 \mathrm{~g}$ mixed feed was collected and dried in a forced-air oven at $60^{\circ} \mathrm{C}$ for $48 \mathrm{~h}$ and ground through a 1$\mathrm{mm}$ sieve before being analyzed. The DM, ash, and $\mathrm{N}$, contents were determined according to the AOAC (1999). The NDF and ADF contents were analyzed according to Van Soest et al. (1991).

Blood samples of all yaks were collected from the jugular vein at the 60 th $\mathrm{d}$ of the trial $(3 \mathrm{~h}$ after the morning
Table 1. Ingredients and nutrient composition of the diets in each group $(\%$, Ingredient composition with air dried basis and nutrient composition with DM basis)

\begin{tabular}{|c|c|c|c|c|}
\hline \multirow{2}{*}{ Items } & \multicolumn{4}{|c|}{ Treatments $^{1}$} \\
\hline & A & $\mathrm{B}$ & $\mathrm{C}$ & $\mathrm{D}$ \\
\hline \multicolumn{5}{|l|}{ Ingredient composition } \\
\hline Corn straw & 70.00 & 60.00 & 50.00 & 40.00 \\
\hline Corn & 18.00 & 24.00 & 30.00 & 36.00 \\
\hline Wheat bran & 4.50 & 6.00 & 7.50 & 9.00 \\
\hline Soybean meal & 3.65 & 4.86 & 6.08 & 7.30 \\
\hline Corn protein powder & 1.15 & 1.53 & 1.92 & 2.30 \\
\hline Rapeseed meal & 1.50 & 2.00 & 2.50 & 3.00 \\
\hline Calcium carbonate & 0.33 & 0.44 & 0.56 & 0.67 \\
\hline Calcium hydrogen phosphate & 0.20 & 0.27 & 0.34 & 0.40 \\
\hline Sodium sulphate & 0.13 & 0.18 & 0.22 & 0.26 \\
\hline Sodium bicarbonate & 0.15 & 0.20 & 0.25 & 0.29 \\
\hline Salt & 0.20 & 0.27 & 0.34 & 0.40 \\
\hline Choline chloride & 0.02 & 0.03 & 0.04 & 0.04 \\
\hline Mineral-vitamin premix ${ }^{2}$ & 0.17 & 0.22 & 0.28 & 0.34 \\
\hline \multicolumn{5}{|l|}{ Nutrient composition } \\
\hline $\mathrm{DM}$ & 83.33 & 84.39 & 85.45 & 86.50 \\
\hline $\mathrm{CP}$ & 9.13 & 10.50 & 11.86 & 13.22 \\
\hline Ether extract & 2.10 & 2.37 & 2.64 & 2.90 \\
\hline NDF & 53.84 & 48.36 & 42.88 & 37.40 \\
\hline $\mathrm{ADF}$ & 32.89 & 29.11 & 25.33 & 21.54 \\
\hline Ash & 5.83 & 5.42 & 5.01 & 4.60 \\
\hline Calcium & 0.50 & 0.53 & 0.56 & 0.59 \\
\hline Phosphorus & 0.37 & 0.40 & 0.44 & 0.47 \\
\hline
\end{tabular}

DM, dry matter; CP, crude protein; NDF, neutral detergent fiber; ADF, acid detergent fiber.

${ }^{1}$ Treatments were: A, F:C $=70: 30 ; \mathrm{B}, \mathrm{F}: \mathrm{C}=60: 40 ; \mathrm{C}, \mathrm{F}: \mathrm{C}=50: 50 ; \mathrm{D}$, $\mathrm{F}: \mathrm{C}=40: 60$

${ }^{2}$ Provided per kilogram of complete diet: vitamin A 1,500 IU; vitamin D $550 \mathrm{IU}$; vitamin E $10 \mathrm{IU}$; Fe (as ferrous sulfate) $20 \mathrm{mg}$; Mn (as manganese sulfate) $40 \mathrm{mg}$; Zn (as zinc sulfate) $30 \mathrm{mg}$; I (as potassium iodide) $0.50 \mathrm{mg}$; $\mathrm{Se}$ (as sodium selenite) $0.30 \mathrm{mg}$; $\mathrm{Co}$ (Cobalt chloride).

feeding) by heparinized syringe. Samples were centrifuged at $3,500 \times \mathrm{g}$ for $15 \mathrm{~min}$ at $4^{\circ} \mathrm{C}$, and the collected serum samples were immediately transported to the laboratory and frozen at $-20^{\circ} \mathrm{C}$ until analyzed. Serum concentrations of urea-N, total protein (TP), albumin (ALB), globulin (GLO), triglyceride (TG), cholesterol (CHO), high density lipoprotein (HDL), low density lipoprotein (LDL), glycerin alanine aminotransferase (ALT), aspartate aminotransferase (AST) were determined using an auto-analyzer (Tekang Technology Co., Ltd. Shanghai, China).

At the 61th-64th $d$ after the experiment, 6 yaks of each group were slaughtered (total 24 yaks) according to local customs and $100 \mathrm{~mL}$ sample of ruminal fluid ( $3 \mathrm{~h}$ after the morning feeding) was rapidly collected. The rumen content was squeezed through 4 layers of cheesecloth under continuous flushing with $\mathrm{CO}_{2}$, The $\mathrm{pH}$ was measured immediately after sampling with a portable $\mathrm{pH}$ meter (Kadiya, 6010, Shenzhen, China). Then, $5 \mathrm{~mL}$ of strained 
Table 2. Effects of forage:concentrate ratio on performance in housing-feeding yak

\begin{tabular}{|c|c|c|c|c|c|c|}
\hline \multirow{2}{*}{ Items } & \multicolumn{4}{|c|}{ Treatments $^{1}$} & \multirow{2}{*}{$\mathrm{SEM}^{2}$} & \multirow{2}{*}{$\mathrm{p}$-value } \\
\hline & A & B & $\mathrm{C}$ & $\mathrm{D}$ & & \\
\hline Initial BW (kg) & 209.53 & 207.84 & 206.90 & 207.30 & 0.58 & 0.388 \\
\hline Final BW (kg) & $239.29^{b}$ & $241.71^{b}$ & $252.15^{\mathrm{a}}$ & $255.9^{\mathrm{a}}$ & 1.75 & $<0.001$ \\
\hline DMI $(\mathrm{kg} / \mathrm{d})$ & $5.33^{\mathrm{b}}$ & $5.31^{\mathrm{b}}$ & $5.66^{\mathrm{a}}$ & $5.63^{\mathrm{a}}$ & 0.04 & $<0.001$ \\
\hline $\mathrm{ADG}(\mathrm{kg} / \mathrm{d})$ & $0.50^{\mathrm{b}}$ & $0.57^{\mathrm{b}}$ & $0.76^{\mathrm{a}}$ & $0.81^{\mathrm{a}}$ & 0.03 & $<0.001$ \\
\hline $\mathrm{G}: \mathrm{F}^{3}$ & $0.093^{\mathrm{b}}$ & $0.108^{\mathrm{b}}$ & $0.133^{\mathrm{a}}$ & $0.142^{\mathrm{a}}$ & 0.0045 & $<0.001$ \\
\hline
\end{tabular}

$\mathrm{BW}$, body weight; DMI, dry matter intake; ADG, average daily gain.

${ }^{1}$ Treatments are including: A, F:C $=70: 30 ; B, F: C=60: 40 ; C, F: C=50: 50 ; D, F: C=40: 60$.

${ }^{2}$ SEM, standard error of the mean between the four groups.

${ }^{3}$ Gain:feed, calculated as total BW gain divided by total feed intake (DM basis).

${ }^{\mathrm{a}, \mathrm{b}}$ Means with uncommon superscripts differ $(\mathrm{p}<0.05)$.

fluid was acidified with $5 \mathrm{~mL}$ of $0.5 \mathrm{M} \mathrm{HCl}$ and frozen for $\mathrm{NH}_{3}-\mathrm{N}$ analysis. For VFA analysis, $800 \mu \mathrm{L}$ of a solution made up of orthophosphoric and crotonic acids (as internal standard) diluted in $0.5 \mathrm{M} \mathrm{HCl}$ was added to $800 \mu \mathrm{L}$ of strained rumen liquid and then frozen. The $\mathrm{NH}_{3}-\mathrm{N}$ concentration was determined by a colorimetric method (Weatherburn, 1967), and VFA were analyzed by gas chromatography (Isac et al., 1994).

\section{Statistical analysis}

All data were analyzed as a completely randomized design using one-way analysis of variance with Duncan multiple comparison test using the general linear model procedure (SPSS, 2009), the fixed factor was diet. Variability in the data is expressed as the standard error means (SEM) and a probability level of $\mathrm{p}<0.05$ was considered to be statistically significant. And The $p$ values between 0.05 and 0.10 were considered as a trend.

\section{RESULTS}

Feed intake and performance

Dry matter intake and performance data are presented in
Table 2. Initial BW did not differ among the experimental treatments $(p=0.388)$, but experimental treatments influenced final BW, DMI, ADG $(\mathrm{p}<0.05)$, the $\mathrm{C}$ and D group increased $(p<0.05) \mathrm{DMI}$ and $\mathrm{ADG}$ compared with the treatments of $\mathrm{A}$ and $\mathrm{B}$, respectively. Similarly, feed efficiency, expressed as gain: feed ratio (ADG to DMI ratio), was similar with DMI and ADG.

\section{Ruminal fermentation}

The ruminal $\mathrm{pH}$ value was decreased $(\mathrm{p}<0.05)$ in the yaks fed the $\mathrm{C}$ and $\mathrm{D}$ diets compared with those fed the $\mathrm{A}$ and $\mathrm{B}$ diets (Table 3). The concentration of ruminal $\mathrm{NH}_{3}-\mathrm{N}$, total VFA, acetate, butyrate, valerate, and isovalerate were not affected $(p>0.05)$ by dietary treatments. The propionate concentration was increased $(p<0.05)$ in the $C$ and $D$ groups relative to the $\mathrm{A}$ and $\mathrm{B}$ diets. And the isobutyrate presented a similar tendency $(\mathrm{p}<0.05)$. In contrast, the acetate to propionate ratio was decreased and was lowest $(p<0.05)$ in the $\mathrm{C}$ group relative to the $\mathrm{A}$ and $\mathrm{B}$ diets, but was similar with the D group.

\section{Blood metabolites}

No difference was found in serum concentrations of

Table 3. Effects of forage:concentrate ratio on rumen fermentation characteristics in housing-feeding yak

\begin{tabular}{|c|c|c|c|c|c|c|}
\hline \multirow{2}{*}{ Item } & \multicolumn{4}{|c|}{ Treatments $^{1}$} & \multirow{2}{*}{$\mathrm{SEM}^{2}$} & \multirow{2}{*}{ p-value } \\
\hline & A & $\mathrm{B}$ & $\mathrm{C}$ & $\mathrm{D}$ & & \\
\hline$\overline{\mathrm{pH}}$ & $6.48^{\mathrm{a}}$ & $6.41^{\mathrm{a}}$ & $6.27^{\mathrm{b}}$ & $6.29^{\mathrm{b}}$ & 0.019 & $<0.001$ \\
\hline $\mathrm{NH}_{3}-\mathrm{N}(\mathrm{mg} / \mathrm{dL})$ & 25.58 & 27.75 & 29.04 & 29.79 & 0.721 & 0.178 \\
\hline \multicolumn{7}{|l|}{ VFA (mmol/L) } \\
\hline Total VFA & 64.02 & 62.14 & 60.83 & 61.15 & 0.753 & 0.593 \\
\hline Acetate & 42.83 & 41.86 & 38.81 & 39.66 & 0.725 & 0.304 \\
\hline Propionate & $13.39^{\mathrm{bc}}$ & $13.05^{\mathrm{c}}$ & $14.58^{\mathrm{a}}$ & $14.15^{\mathrm{ab}}$ & 0.177 & 0.020 \\
\hline Butyrate & $4.59^{\mathrm{a}}$ & $3.76^{\mathrm{a}}$ & $4.02^{\mathrm{a}}$ & $3.69^{\mathrm{a}}$ & 0.145 & 0.109 \\
\hline Isobutyrate & 1.12 & 1.34 & 1.28 & 1.26 & 0.031 & 0.057 \\
\hline Valerate & 0.69 & 0.71 & 0.63 & 0.68 & 0.020 & 0.547 \\
\hline Isovalerate & 1.50 & 1.52 & 1.59 & 1.79 & 0.059 & 0.316 \\
\hline Acetate:propionate & $3.20^{\mathrm{a}}$ & $3.22^{\mathrm{a}}$ & $2.67^{\mathrm{b}}$ & $2.82^{\mathrm{ab}}$ & 0.074 & 0.034 \\
\hline
\end{tabular}

VFA, volatile fatty acids.

${ }^{1}$ Treatments are including: A, F:C = 70:30; B, F:C =60:40; C, F:C = 50:50; D, F:C = 40:60.

${ }^{2}$ SEM, standard error of the mean between the four groups.

${ }^{\mathrm{a}, \mathrm{b}}$ Means with uncommon superscripts differ $(\mathrm{p}<0.05)$. 
urea-N, ALB, TG, CHO, LDL, ALT, and AST ( $\mathrm{p}>0.05)$ among treatments (Table 4). Treatment $\mathrm{C}$ had a higher concentrations of TP and HDL $(p<0.05)$ than those in the A and $\mathrm{B}$ groups. The concentration of HDL with A $(0.53$ $\mathrm{mmol} / \mathrm{L})$ and $\mathrm{B}(0.67 \mathrm{mmol} / \mathrm{L})$ treatments was not different $(\mathrm{p}<0.05)$, but was contrary in TP concentration. In addition, there was a trend that the GLO concentration of A group was lower than other treatments $(p=0.079)$.

\section{DISCUSSION}

\section{Feed intake and performance}

There is little information on the effects of $\mathrm{F}$ : $\mathrm{C}$ ratio on DMI and growth performance in housing-feeding yaks, but it has been well studied in other ruminants. CantalapiedraHijar et al. (2014) observed DMI was not affected with the percentage of concentrate increasing in the diet from $30 \%$ to $70 \%$ in goats. Aguerre et al. (2011) found that increasing $\mathrm{F}: \mathrm{C}$ ratios $(47: 53,54: 46,61: 39$, and 68:32) in the diet had no effect on DMI of Holstein cows. A similar result was observed by Agle et al. (2010), who reported no change in DMI of lactating dairy cows fed diets contained $52 \%$ and $72 \%$ concentrate feeds. In contrast, Desnoyers et al. (2008) reported that DMI of dairy goats was increased (2.69 to $2.88 \mathrm{~kg} / \mathrm{d}$ ) with increasing the percentage of concentrate in the diet from $30 \%$ to $60 \%$. Similarly, Murphy et al. (2000) noted that cows fed 30:70 diets of $\mathrm{F}: \mathrm{C}$ ratio had a significantly higher DMI than cows fed 50:50 diets. In agreement with their results, this study showed that diets with lower F:C ratios increased DMI of housed-fed yaks. The reason may be related to the low rumen fill effect of concentrate compared to roughage (Jarrige et al., 1995). On the other hand, in our study, corn straw that had inferior nutrient value and palatability was the only roughage fed to yaks, therefore, increasing level of concentrate probably improved the palatability and then promoted the feed intake.

In agreement with the result in the present study, many of results have reported that lower $\mathrm{F}: \mathrm{C}$ ratios improved the performance compared with diets that had higher roughage levels in dairy cows, goats, and lambs (Hartman et al., 1959; Jabbar and Anjum, 2008; Serment et al., 2011; Kargar et al., 2012). These findings might be related to a greater nutrient intake, such as rapidly fermentable carbohydrate and quality protein, and higher nutrient digestibility found in high level of concentrate diets compared to lowconcentrate diets (Cantalapiedra-Hijar, 2014). However, in our study, no difference was found with the ADG of yaks fed $50 \%$ and $60 \%$ concentrate in the diet, which may be due to the greater digestibility of diet with $\mathrm{C}$ than in $\mathrm{D}$ group. Therefore, under this experimental condition, the $50 \%$ concentrate was considered optimal ratio for diet to housedfed yaks.

\section{Ruminal fermentation characteristics}

The findings of the present study for ruminal $\mathrm{pH}$ value were in line with previous researches (Hadjipanayiotou and Antoniou, 1983; Cerrillo et al., 1999). Greater amounts of starch in higher concentrate diets may yield greater lactic acid concentration (Slyter, 1976), and hence lower ruminal $\mathrm{pH}$ value compared with lower concentrate diets. However, the $\mathrm{pH}$ values in the current study ranged from 6.27 to 6.48 and seemingly did not induce acidosis that is usually defined as a decrease in rumen $\mathrm{pH}$ below a threshold value of 6.0 (Nocek, 1997).

The effects of $\mathrm{F}: \mathrm{C}$ ratios on concentration of $\mathrm{NH}_{3}-\mathrm{N}$, total VFA and individual VFA concentration in ruminants have been investigated widely, but the results were inconsistent. In accordance to previous researches (Carro et al., 2000; Agle et al., 2010; Aguerre et al., 2011), our results showed that $\mathrm{F}: \mathrm{C}$ ratios did not significantly affect $\mathrm{NH}_{3}-\mathrm{N}$

Table 4. Effects of forage:concentrate ratio on blood metabolites in housing-feeding yak

\begin{tabular}{|c|c|c|c|c|c|c|}
\hline \multirow{2}{*}{ Item } & \multicolumn{4}{|c|}{ Treatments $^{1}$} & \multirow{2}{*}{$\mathrm{SEM}^{2}$} & \multirow{2}{*}{ p-value } \\
\hline & A & B & $\mathrm{C}$ & D & & \\
\hline Urea N (mmol/L) & 2.31 & 2.40 & 2.76 & 2.71 & 0.118 & 0.454 \\
\hline $\mathrm{TP}(\mathrm{g} / \mathrm{L})$ & $82.38^{\mathrm{c}}$ & $86.67^{\mathrm{bc}}$ & $90.10^{\mathrm{a}}$ & $88.38^{\mathrm{ab}}$ & 0.886 & 0.008 \\
\hline $\operatorname{ALB}(g / L)$ & 18.55 & 18.95 & 19.76 & 19.87 & 0.309 & 0.374 \\
\hline GLO (g/L) & 63.56 & 67.50 & 70.16 & 67.71 & 0.923 & 0.079 \\
\hline TG (mmol/L) & 0.49 & 0.47 & 0.58 & 0.54 & 0.019 & 0.214 \\
\hline $\mathrm{CHO}(\mathrm{mmol} / \mathrm{L})$ & 1.45 & 1.48 & 1.46 & 1.39 & 0.041 & 0.894 \\
\hline HDL (mmol/L) & $0.53^{\mathrm{d}}$ & $0.67^{b c}$ & $0.75^{\mathrm{a}}$ & $0.71^{\mathrm{ab}}$ & 0.018 & $<0.001$ \\
\hline $\mathrm{LDL}(\mathrm{mmol} / \mathrm{L})$ & 0.56 & 0.54 & 0.55 & 0.57 & 0.014 & 0.929 \\
\hline $\operatorname{ALT}(\mu / \mathrm{L})$ & 35.14 & 35.27 & 35.70 & 36.84 & 0.550 & 0.705 \\
\hline $\operatorname{AST}(\mu / L)$ & 67.52 & 68.22 & 69.53 & 68.23 & 0.86 & 0.879 \\
\hline
\end{tabular}

TP, total protein; ALB, albumin; GLO, globulin; TG, triglyceride; CHO, cholesterol; HDL, high density lipoprotein; LDL, low density lipoprotein; ALT, alanine aminotransferase; AST, aspartate aminotransferase.

${ }^{1}$ Treatments are including: A, F:C = 70:30; B, F:C = 60:40; C, F:C = 50:50; D, F:C = 40:60.

${ }^{2} \mathrm{SEM}$, standard error of the mean between the four groups.

a,b,c,d Means with uncommon superscripts differ $(\mathrm{p}<0.05)$. 
and total VFA concentrations in the rumen. In contrast, Manatbay et al. (2014) reported that lower F:C ratios of substrates significantly increased $\mathrm{NH}_{3}-\mathrm{N}$ and total VFA concentration compared with the higher forage substrates in vitro study. Several possible explanations exist for this difference. Firstly, it might be due to the rumen ecosystem of yaks being able to adapt the appropriate changes of $F: C$ ratios in our experiment via the self-adjustment of rumen microorganism. In addition, yaks fed the lower $\mathrm{F}$ : $\mathrm{C}$ ratios (40:60 and 50:50) diets might have near a similar degradation rate between protein and carbohydrate, which then increased the growth yield of ruminal bacteria compared with the higher $\mathrm{F}: \mathrm{C}$ ratios (60:40 and 70:30) diets as Russell et al. (1992) demonstrated, and hence they had no difference of $\mathrm{NH}_{3}-\mathrm{N}$ and total VFA concentrations in the rumen. As for the individual VFA concentration, consistent with our results, the expected increase in propionate concentrations and reduce in acetate to propionate ratio with high level of concentrate appeared to be achieved in several studies (Andrade and Schmidely, 2006; Gengzhi et al., 2014; Polyorach et al., 2014). Moreover, the other individual VFA concentrations had no difference among treatments, indicating that no acute change occurred within the rumen ecosystem of yaks in different $\mathrm{F}: \mathrm{C}$ ratios in our trial.

\section{Blood metabolites}

Blood metabolites are important indicators of general health and vitality, and may reflect the function of certain tissues and organs. The urea $\mathrm{N}$ is a product of protein and amino acid catabolism in the body, and negatively correlates with nitrogen deposition and protein or amino acid utilization. When amino acids are limited or imbalanced, or when decreased utilization of protein occurs, urea $\mathrm{N}$ content increases (Ponnampalam et al., 2005). In our study, different $\mathrm{F}: \mathrm{C}$ ratios did not affect blood urea $\mathrm{N}$ concentrations. The most likely reason was that urea $\mathrm{N}$ concentration in blood was highly correlated with the rumen $\mathrm{NH}_{3}-\mathrm{N}$ concentration (Petit and Flipot, 1992; Davidson et al., 2003), which was not affected by F:C ratio in our study. In addition, we found that increasing the proportion of concentrate from $30 \%$ to $50 \%$ in diets increased blood TP and GLO (as a trend) concentration in yaks. Namely, the diet with $50 \%$ concentrate probably improved humoral immunity and protein synthesis of the animal (Abonyi et al., 2013). Additionally, HDL helps to prevent narrowing of the artery walls by removing the excess cholesterol and transporting it to the liver for excretion (Kyung et al., 2015). The concentration of HDL was increased with increasing of the concentrate ratio in diets, and this result might be confirmed by no change being observed with blood $\mathrm{CHO}$ concentrations among treatments in our study. Furthermore, the present study showed that the F:C ratios had no effects on hepatic enzymes (ALT and AST), and hence did not seem to have a negative influence on the function of organs associated with blood substances (Vakili et al., 2013 ).

\section{IMPLICATIONS}

The results of this study show that increasing level of concentrate from $30 \%$ to $50 \%$ exerted a positive influence on growth performance, ruminal fermentation, and blood metabolites. Moreover, our study provided evidence that the conventional grazing production systems can be transformed into a housing-feeding strategy successfully to not only improve productive efficiency of yaks but also retard rangeland degradation.

\section{CONFLICT OF INTEREST}

We certify that there is no conflict of interest with any financial organization regarding the material discussed in the manuscript.

\section{ACKNOWLEDGMENTS}

We gratefully thank our labmates in the College of Life Science and Technology of Southwest University for Nationalities for their assistant in this study. This work was supported by the Technology Integration and Demonstration to Production, Ecological environment and Livelihood of Key Grazing Region in China (2012BAD13B06).

\section{REFERENCES}

Abonyi, F. O., N. S. Machebe, M. S. Ezea, J. I. Eze, B. C. Omeke, B. N. Marire. 2013. Effects of substituting soya bean meal (SBM) with blood meal (BM) on biochemical profile of pregnant pigs. Trop. Anim. Health Prod. 45:957-963.

Agle, M., A. N. Hristov, S. Zaman, C. Schneider, P. M. Ndegwa, and V. K. Vaddella. 2010. Effect of dietary concentrate on rumen fermentation, digestibility, and nitrogen losses in dairy cows. J. Dairy Sci. 93:4211-4222.

Aguerre, M. J., M. A. Wattiaux, J. M. Powell, G. A. Broderick, and C. Arndt. 2011. Effect of forage-to-concentrate ratio in dairy cow diets on emission of methane, carbon dioxide, and ammonia, lactation performance, and manure excretion. J. Dairy Sci. 94:3081-3093.

Andrade, P. V. D. and P. Schmidely. 2006. Influence of percentage of concentrate in combination with rolled canola seeds on performance, rumen fermentation and milk fatty acid composition in dairy goats. Livest. Sci. 104:77-90.

AOAC. 1999. Official Methods of Analysis. 17th ed. AOAC Int., Arlington, VA, USA.

Cantalapiedra-Hijar, C., D. R. Yáñez-Ruiz, A. I. Martín-García, and E. Molina-Alcaide. 2014. Effects of forage:concentrate ratio and forage type on apparent digestibility, ruminal fermentation, and microbial growth in goats. J. Anim. Sci. 87:622-631. 
Carro, M. D., C. Valdes, M. J. Ranilla, and J. S. Gonzalez. 2000. Effect of forage to concentrate ratio in the diet on ruminal fermentation and digesta flow kinetics in sheep offered food at a fixed and restricted level of intake. J. Anim. Sci. 70:127-134.

Cerrillo, M. A., J. R. Russell, and M. H. Crump. 1999. The effects of hay maturity and forage to concentrate ratio on digestion kinetics in goats. Small Rumin. Res. 32:51-60.

Chen, Y., M. Oba, and L. L. Guan. 2012. Variation of bacterial communities and expression of Toll-like receptor genes in the rumen of steers differing in susceptibility to subacute ruminal acidosis. Vet. Microbiol. 159:451-459.

Davidson, S., B. A. Hopkins, D. E. Diaz, S. M. Bolt, C. Brownie, V. Fellner, and L. W. Whitlow. 2003. Effects of amounts and degradability of dietary protein on lactation, nitrogen utilization, and excretion in early lactation Holstein cows. J. Dairy Sci. 86:1681-1689.

Desnoyers, M., C. Duvaux-Ponter, K. Rigalma, S. Roussel, O. Martin, and S. Giger-Reverdin. 2008. Effect of concentrate percentage on ruminal $\mathrm{pH}$ and time-budget in dairy goats. J. Anim. Sci. 2:1802-1808

Dong, Q. M., X. Q. Zhao, Y. S. Ma, S. X. Xu, and Q. Y. Li. 2006. Live-weight gain, apparent digestibility, and economic benefits of yaks fed different diets during winter on the Tibetan plateau. Livest. Sci. 101:199-207.

Gengzhi, D., C. Ying, Z. Zhenming, R. Liping, and M. Qingxiang. 2014. Effect of Saccharomyces cerevisiae on rumen fermentation characteristics, nutrient degradation and cellulase activity of steers fed diets with different concentrate to forage ratios. World J. Agric. Res. 2:303-308.

Hadjipanayiotou, M. and T. Antoniou. 1983. A comparison of rumen fermentation patterns in sheep and goats given a variety of diets. J. Sci. Food Agric. 34:1319-1322.

Hartman, R. H., D. L. Staheli, R. G. Holleman, and L. H. Horn. 1959. Effect of stilbestrol and pelleting at two concentrate to roughage ratios on the performance and carcass quality of fattening lambs. J. Anim. Sci. 18:1114-1118.

Isac, M. D., M. A. García, J. F. Aguilera, and E. Molina-Alcaide. 1994. A comparative study of nutrient digestibility, kinetics of digestion and passage and rumen fermentation pattern in goats and sheep offered medium quality forages at the maintenance level of feeding. J. Arch. Tierernahr. 46:37-50.

Jabbar M. A. and M. I. Anjum. 2008. Effect of diets with different forage to concentrate ratio for fattening of Lohi lambs. Pak Vet. J. 28:150-152.

Jarrige R., J. P. Dulphy, P. Faverdin, R. Baumont, and C. Demarquilly. 1995. The nutrition and activities of digestion and rumination in the domestic ruminants. Ingestion et digestion (Ed. M. Journet), pp. 123-181. Institut National de la Recherche Agronomique (INRA), Paris, France.

Kargar, S., G. R. Ghorbani, M. Alikhani, Mohammad, R. Ladan, and J. S. David. 2012. Lactational performance and milk fatty acid profile of Holstein cows in response to dietary fat supplements and forage:concentrate ratio. J. Livest. Sci. 150: 274-283.

Kyung, S., J. G. Nejad, S. M. Hong, S. J. Ohh, B. H. Lee, J. L. Peng, D. H. Ji, and B. W. Kim. 2015. Effects of forage level and chromium-methionine chelate supplementation on performance, carcass characteristics and blood metabolites in Korean native (Hanwoo) steers. Anim. Feed Sci. Technol.
57:1-14.

Long, R. J., L. M. Ding, Z. H. Shang, and X. H. Guo. 2008. The yak grazing system on the Qinghai-Tibetan plateau and its status. Rangeland J. 30:241-246.

Long, R. J., S. K. Dong, X. H. Wei, and X. P. Pu. 2005. The effect of supplementary feeds on the body weight of yaks in cold season. Livest. Prod. Sci. 93:197-204.

Long, R. J., D. G. Zhang, X. Wang, Z. Z. Hu, and S. K. Dong. 1999. Effect of strategic feed supplementation on productive and reproductive performance in yak cows. Prev. Vet. Med. 38:195-206.

Manatbay, B., Y. Cheng, S. Mao, and Z. Weiyun. 2014. Effect of gynosaponin on rumen in vitro methanogenesis under different forage-concentrate ratios. Asian Australas. J. Anim. Sci. 27: 1088-1097.

Morand-Fehr, P. and D. Sauvant. 1987. Feeding strategies in goats. Pages 1275-1303 in Proc. 4th Int. Conf. Goats, Brasilia, Brazil. (Eds. O. P. Santana, A. G. da Silva, and W. C. Foote). Depto. De Difusao de Tecnol., Brasilia, Brazil.

Murphy, M., M. Akerlind, and K. Holtenius. 2000. Rumen fermentation in lactating cows selected for milk fat content fed two forage to concentrate ratios with hay or silage. J. Dairy Sci. 83:756-764.

Nocek, J. E. 1997. Bovine acidosis: Implications on laminitis. J. Dairy Sci. 80:1005-1028.

Petit, H. V. and P. M. Flipot. 1992. Feed utilization of beef steers fed grass as hay or silage with or without nitrogen supplementation. J. Anim. Sci. 70:876-883.

Polyorach, S., M. Wanapat, and A. Cherdthong. 2014. Influence of Yeast fermented cassava chip protein (YEFECAP) and roughage to concentrate ratio on ruminal fermentation and microorganisms using in vitro gas production technique. Asian Australas. J. Anim. Sci. 27:36-45.

Ponnampalam, E. N., A. R. Egan, A. J., Sinclair, and B. J. Leury. 2005. Feed intake, growth, plasma glucose and urea nitrogen concentration, and carcass traits of lambs fed isoenergetic amounts of canola meal, soybean meal and fish meal with orage based diet. Small Rumin. Res. 58:245-252.

Russell, J. B., J. D. O'Connor, D. G. Fox, P. J. Van Soest, and C. J. Sniffen. 1992. A net carbohydrate and protein system for evaluating cattle diets: I. Ruminal fermentation. J. Anim. Sci. 70:3551-3561.

Serment, A., P. Schmidely, S. Giger-Reverdin, P. Chapoutot, and D. Sauvant. 2011. Effects of the percentage of concentrate on rumen fermentation, nutrient digestibility, plasma metabolites, and milk composition in mid-lactation goats. J. Dairy Sci. 94:3960-3972.

Slyter, L. L. 1976. Influence of acidosis on rumen function. J. Anim. Sci. 43:910-929.

Vakili, A. R., B. Khorrami, M. Danesh Mesgaran, and E. Parand. 2013. The effects of Thyme and Cinnamon essential oils on performance, rumen fermentation and blood metabolites in Holstein calves consuming high concentrate diet. Asian Australas. J. Anim. Sci. 26:935-944.

Van Soest, P. J., J. B. Robertson, and B. A. Lewis. 1991. Methods for dietary fiber, neutral detergent fiber, and nonstarch polysaccharides in relation to animal nutrition. J. Dairy Sci. 74:3583-3597.

Weatherburn, M. W. 1967. Phenol-hypochlorite reaction for determination of ammonia. J. Anal. Chem. 39:971-974. 